\title{
The Afterglow of the Roman Republic: Becoming an Empire without an Emperor
}

\author{
Bincheng Mao \\ Liberal Studies, New York University, New York, USA \\ Email: binchengmao@foxmail.com
}

How to cite this paper: Mao, B.C. (2019) The Afterglow of the Roman Republic: Becoming an Empire without an Emperor. Open Journal of Social Sciences, 7, 273-282. https://doi.org/10.4236/jss.2019.79021

Received: July 29, 2019

Accepted: September 24, 2019

Published: September 27, 2019

Copyright (c) 2019 by author(s) and Scientific Research Publishing Inc. This work is licensed under the Creative Commons Attribution-NonCommercial International License (CC BY-NC 4.0). http://creativecommons.org/licenses/by-nc/4.0/

\begin{abstract}
This paper demonstrates the process of transformation between the Roman Republic and the Roman Empire. It examines whether Augustus, the traditionally considered first emperor of Rome, indeed marked the beginning of the Roman Empire. This paper analyzed the specific political performances of Roman leaders before Augustus, including the Gracchus brothers, Sulla, and Caesar, and compared them to Plato's and Cicero's definitions of an ideal republican governing system. In the end, it is proved that Rome had become an empire even before it had an emperor. During the course of research, the author employed the method of source criticism, in which he collected primary and secondary sources and evaluated their relevance to either a republican government or an empire.
\end{abstract}

\section{Keywords}

Roman Empire, Transformation of Governing Systems, Greek and Roman Political Philosophy, Transformation of Political Cultures

\section{Introduction}

The end of the Roman Republic marked one of the most significant turning points in ancient history; and it was this very process of gradual dissolution of the republican governing system that provided room for the rise of an imperial governing system in Rome. Therefore, it was the objective of the author to investigate the exact moment that marked the end of the Roman Republic in order to enable future researchers to accurately evaluate such an event's influence, with the research question of this paper being whether Rome had become an empire even before it had an emperor. The transformation of Rome from a republic to an empire was a result of many factors. Although traditionally, many historians regard the Roman Empire to have appeared in the year 27 BC in which Octavian 
was given the title "Augustus," setting the Roman governing system to a principate, virtually an empire. However, after examining the political performances of the late Roman Republic, the state had, in fact, no longer fit the essence of republics defined by Plato and Cicero, yet fit their definitions of empires. Therefore, Augustus's principate merely established the name of the empire but not its essence which was formed long before him. As a result, regarding the establishment of Rome as an empire, people should focus on its essence rather than its name.

\section{The Criteria of a Republican Government and an Empire}

\subsection{The Republican Governing System from Plato's Perspective}

Plato was one of the very first political philosophers who established the theoretical basis for a republican governing system. After Rome conquered Greece in 146 BC, Rome absorbed many of the more advanced Greek philosophical theories into the Roman sphere, including Plato's ideal for a republican government. Therefore, Plato's description of the republican system can be seen as the political foundation for the Roman Republic, and if the policies of the traditionally considered Roman Republic contradicted with Plato's definitions, the republican system was no longer functioning.

From Plato's perspective, the purpose of establishing republics, or in the Greek city states in Plato's time, is to live a self-sustainable life. In order to achieve this purpose, it is necessary for each state to have citizens from various occupations. In other words, every citizen is a foundation upon which the state is formed and every citizen holds a part of the state. In his philosophical masterpiece Republic, Plato discusses five types of regimes, including Aristocracy, Timocracy, Oligarchy, Democracy, and Tyranny. In his mind, Aristocracy, which has a different meaning than the modern term, is the relatively most ideal form of government among the five regimes. It is a state ruled by the wise, forming a society of law, order, and wisdom. The second type of regime is Timocracy, which is ruled by honor and duty. Plato uses Sparta as an example in Republic. The third type of regime is Oligarchy in which a state is ruled by wealth and land ownership. An example is a free-trading city that follows market-based ethics. The fourth type of regime is democracy, which is ruled by pure freedom and equality, or "ruled by the many" [1]. Even though Plato ranked the four types of regimes mentioned above, all these are still ideal forms of government. According to "Amicitia' in the Late Roman Republic" published by The Cambridge Classical Journal, the political support for candidates for office only matters when there is a republic [2]. In Republic, Plato argues that when democracy collapsed, societies will turn into tyrannies, which is ruled by despots with absolute powers. Then, Plato explains that the most ideal form, an "ideal polity", is a "balanced" mixed-republic that draws from all the forms except tyranny [3]. The fact that Plato excluded tyranny and regarded all the other forms as republics proves that the very essence of a republic to avoid tyranny. From this perspec- 
tive, the qualities that only tyranny has but not the other four regimes are the fundamental characteristics that determine whether or not a government is a republic. Therefore, the existence of a just and comprehensive legal system proves that a state is ruled by law; and the existence of a set of functioning checks and balances that limit the power of officials proves that the governments do not hold absolute powers.

\subsection{The Republican Governing System from Cicero's Perspective}

Roman orator and philosopher Cicero concluded in his book Du re Publica that "res populi" [4], meaning that the republic is the property of the people. In other words, the republic is not the property of one man or a small group of men, and every citizen, including those ruled by the republican government, have the right to participate in governance since the republic is their property. Later generations summarized this theory as popular sovereignty, and it becomes a fundamental characteristic of the republican governing system. Cicero also defined the concept of "populous" [4] or "people" as individuals who are bonded by a shared value of "beneficentia", [4] which means justice and generosity, and had a common hope for advancing their public interests. Therefore, from Cicero's perspective, states that have its people being the sovereigns and seek to maintain justice as well as to further the interests of the public can be considered as a republic.

\subsection{The Criteria for an Empire}

Traditionally, the formations of empires are associated with one single ruler with absolute powers, virtually an emperor. This is the narrow definition of an empire. The essence of this definition is that the presence of one authoritarian authority with no checks on balances over its power makes a state an empire. However, since this definition narrows the ruler down to one single person, the emperor, many states that essentially fit the criteria are not considered an empire. Therefore, a broader definition of the same essence was formed to better define empires: any major political units ruled by one single authority which has no checks over its power.

\section{The Social and Political Foundations for Transforming Rome into an Empire without an Emperor}

\subsection{The Economic Foundation}

During the middle and late Roman Republic, one trend that coincided with the large-scale bankruptcy of the small farming economy was the rapid development of latifundia owned by the noble class of Rome. Due to years of military service, a massive number of middle class men were unable to manage their small farms, which made the land desolate. The nobles took the opportunity to incorporate these small farms using their financial resources and political power, expanding their farms into latifundia. Over time, these latifundia were growing increasing rapidly. Regarding the size of latifundia owned by the nobility during the late 
Roman Republic, Pliny the Elder, a Roman author active in the first century CE, once described it in his encyclopedic Naturalis Historia: "In the province of Africa, six landlords held half the lands in the province" [5]. As the system of latifundia developed and the small farming economy disappeared, large numbers of small farmers lost their source of income and fell into poverty due to the influx of cheap labor force of slaves which prevented these previous small farmers from even working in the newly formed latifundia as serfs. In the end of the first century BCE, the slave economy became the backbone of agriculture in the Roman Republic. Accordingly, from an economic perspective, the fall of the small farming economy and the rise of its replacement, latifundia, which used cheap labor, resulted in a massive spread of poverty among the previous middle class and therefore dramatically increased the proportion of impoverished population in the Roman Republic. There is an argument by Materialism, a branch of philosophy that emphasizes the essentiality of matter, which explains this circumstance and its consequences very well: "The mode of production of material life conditions the general process of social, political and intellectual life" [6]. When individuals can feed and clothe themselves, they will have higher spiritual pursuits and political needs. Yet, if individuals cannot even sustain their basic survival, which may very well be the case for the previous middle class men who fell into poverty as they lost their farms, the needs for spiritual and political pursuits, such as maintaining a glorious republican governing system, no longer existed. Therefore, the economic situation of the late Roman Republic lays the foundation for an imperial governing system to appear.

\subsection{The Political-Structural Foundation for Transforming Rome into an Empire before Augustus}

During the expansion of state, the Roman republican governing system apparently did not catch up with the pace of the states' territorial expansion. Robert Hayward Barlow, an American historian and avant-garde poet, once concluded: "The experience of the Romans was displaced in a series of systems, rules, and ideals. Yet, in the first century BCE, all of these were abandoned because of their fundamental flaws. Therefore, the abandonment was a natural result of human nature" [7].

Under the system of the traditionally considered Roman Republic, Dictator was an extraordinary magistrate entrusted with full authority of the republic under a state of emergency. As described in Corpus Juris Civilis wrote by Emperor Justinian of the Eastern Roman Empire, "The people have no right to appeal to a dictator, but even give him the power to impose the death penalty" [8]. This dictator, as accounted by Francesco De Martino, an Italian jurist and former deputy prime minister, "was not bound by the instructions of the Senate, nor does it have to report his work" [9]. To some extent, dictatorship was a temporary recovery of a regal government.

As Rome achieved a series of victories and expanded its territory, a provincial governing system was implemented in the newly conquered areas. Sardinia Cor- 
sica is the second province established by the Roman Republic, since then, Rome began to elect government officials to be governors in these provinces. By the time of Sulla, Rome had established 10 provinces. By the time of Caesar, 14 provinces were established in total. As the number of provinces increased, ultimately the power of choosing governors for these provinces resided in the Senate. Due to the unpredictability of the results of foreign war in the early Roman Republic, this made the governance of newly acquired territory after the victories lack a timely and reasonable preparation and governing mechanism to a certain extent, which resulted in an imperfect provincial government. At the end of the Republican period, the province gradually became the base and capital for the governor's power grab, which constituted a great impact on the principles of the Roman Republic. For instance, the governorships of three provinces gave Caesar military resources to win the civil war.

Furthermore, from 91 to $88 \mathrm{BCE}$, the Italian allies initialed the Social War against Rome, for the republic refused to granted the allies Roman citizenship which the allies believed they deserved. This war unintended made Sulla the most powerful man in Rome. When the Social War gradually became a grand civil war, King Mithridates of Pontus and Armenia Minor in northern Anatolia initiated another war against Rome. Sulla was given the power of command for the war in the east and ultimately defeated Mithridates. Sulla then led his army to defeat his political opponents by forcefully taking over Rome, establishing a military dictatorship. The governing system of dictatorship fundamentally contradicted the republican system, therefore marking the end of the Roman republican system and paving the way for a new form of government to take over.

\subsection{The Military Foundation for Transforming the Republic into an Empire without an Emperor}

Ever Since the reform of Servius Tullius, Rome used a complete system of citizen militias based on a certain property qualification to serve as the armed forces of the state. The first step that Rome took towards a professional army was the siege of Veii in 396 BCE. It was the first time that the state "offered payments to the soldiers" [10] in order to keep them fighting the battle. When Marius replaced the forceful conscription of financially able citizens with voluntary enlistment in his military reform, the citizen militias system became weaker and weaker whereas professional armies started to form. With the decline of the citizen militia system and the rise of the professional standing army, the nature of the Roman army was gradually changing.

During the era of the citizen militia system, Roman soldiers considered serving in the army as both an honor and an obligation. They were not getting payments for their years of war efforts since they joined the army to fulfill their civic duty. However, after the rise of the professional army system, soldiers joined the army not to fulfill a duty but to get the rewards. They considered being soldiers as an occupation. When the wars are over, these soldiers would get their rewards from their generals, even though many times their generals acquired these re- 
wards from the Senate. As time went on, these professional soldiers no longer serve the republic but their generals who would give them rewards. Meanwhile, some of the generals also began to use the army as a means to further their own interests, and the army therefore gradually became a tool for political power grab. This shift of goals became an enormous threat to the republican system. The great French philosopher Montesquieu explained this in his book, Considerations on the Causes of the Greatness of the Romans and their Decline, that "when Rome only ruled Italy, the republic was easy to maintain since the soldiers would also follow the next consul when the term of the man who drafted them ended" [11]. Yet, "when the legion crossed the Alps and the sea, the soldiers had to stay in the places they conquered, they gradually lost the spirit that citizens should have, and therefore strengthened the power of their generals. As a result, these generals no longer wanted to take orders from the republic" [11]. From this point on, the Roman army became the ultimate source of power of the state as they serve as the compelling force to advance their leaders' interests. In this case, their leaders were not the republic but the generals.

At this point, the military system already formed the foundation for an empire to appear in Roman territory.

\section{The Political Performances of the Late Roman Republic}

\subsection{The Reform of Tiberius Gracchus}

Tiberius Gracchus was a great politician and reformer in the traditionally regarded Roman Republic.

In the middle to late Roman Republic, constant victories of foreign wars made Rome the dominator of the Mediterranean world. Large number of captured people allowed the slave economy to grow rapidly Rome, yet this form of economy also caused a severe internal problem. Years of foreign wars bankrupted many previous middle class men who were obligated to join the army and the spread of Latifundia and other industries that used slaves as cheap labor made these people fall into poverty since they could not get any jobs. This created a manpower shortage under the citizen militia system due to the strict property qualifications for drafting soldiers. It is in this context that the Gracchus brothers launched a series of reforms.

Tiberius Gracchus set land reforms as the core of his program, aiming to restrict the trend of the noble class incorporating small farms owned by the newly impoverished soldiers. Hoping to initiate his reform program smoothly, Tiberius challenged Roman traditional customs multiple times. For instance, he bypassed the Senate and directly proposed his reform program to the citizens. He also deposed his fellow tribune, who was a conservative and tried to veto his reform program, through public voting. He even tried to get elected tribune of the people multiple times. Tiberius's reforms hurt the vested interests of the noble class since they were the owners of the latifundia throughout the nation. Ultimately, a group of senators massacred Tiberius and his followers at an assembly 
of citizens. The Tiberius Gracchus reform ended with a brutal murder.

Even though Tiberius Gracchus's reform was based on the intentions of benefiting the states, his way of conducting this reform hurt the fundamental values of the Roman Republic as well. Under the republic's law, tribunes were able to veto any magistrates' policies, including his fellow tribunes. This was an example of the system of checks of balances in the Roman republic. Therefore, Tiberius's decision of overturning the conservative tribune's veto through deposing him using public votes fundamentally hurt the republican governing system since it eliminated checks and balances. Also, Roman laws prohibited tribunes from getting reelected immediately after their first term, yet Tiberius decided to run for reelection broke this law which was intended to limit the power of government officials. By doing this, Tiberius eliminated another system of checks and balances. As a result, the so-called Roman Republic was no longer a true republic to some extent, for according to Plato's definition, a state with no checks and balances is not a republic.

\subsection{The Sulla Dictatorship}

At the end of the second century $\mathrm{BC}$, the previous struggle of the plebeians against the nobles in Rome led to a conflict between progressives and conservatives in Roman politics. The progressives and conservatives both claimed to seek to further the interests of the republic, yet in reality leaned separately towards the two sides of the previous struggle. The progressives considered advancing the interests of the plebeians and the conservatives focused more on protecting the interests of the traditional ruling class. They fought fiercely against each other for their interests. From the initial murders and riots to large-scale military invasions later on, the means of these conflicts were becoming increasingly extreme, and the Sulla Dictatorship was a direct result of such a military conquest.

Ever since this precedent set by Sulla, military dictatorships began to form within the traditionally regarded Roman Republic. С.И.Ковалев, a Russian historian specialized in Ancient Greece and Roman history concluded that "this was a rather natural progression, for their rules directly depended on the power of armies. These armies though were legally still citizen militias, were in fact private armies before the traditionally regarded end of the Roman republic" [12]. Sulla himself wished to establish a permanent aristocracy in which the traditional nobles could rule Rome indefinitely. When he defeated his political opponents one by one using the force of his army, Sulla implemented a series of policies to restore and maintain the traditional Roman republican system which had arguably failed. Nevertheless, his rule over Rome contradicts with the goals of his reform program. More importantly, Sulla held unchecked authority over the state of Rome during his dictatorship, greatly contradicting with Plato's idea that a republican governing system must have checks and balances to make sure that no one is holding absolute power. In conclusion, since Sulla's way of governing the so-called Roman Republic violated Plato's definition of a republic, which the 
very foundation of the Roman Republic, Rome was no longer a republic at this point.

\subsection{Dictatorships of Caesar and Pompeius}

In order to deal with the issues of piracy and inflation, in $67 \mathrm{BC}$, "Pompeius's ally Gabinius proposed a law that enabled Pompeius to control 50 miles of inward lands around the Mediterranean coastline as well as granting him imperium over all Roman fleets for three years" [13]. This proposed was overwhelming rejected by almost all the senators except Caesar and few of Pompeius' supporters. However, under the influence of Caesar and Pompeius, this proposal was ultimately passed. "The Senate had to give 125,000 soldiers and the Roman fleet of 500 warships to Pompeius, and also ordered the treasury to distribute 144 million sesterce to cover the military expense." Soon afterwards, Pompeius's another ally, Manilius, proposed another act, asking the Senate to extend the Gabinius Law. The Senate refused, yet the citizen assembly soon passed Manilius's proposal [14]. The passage of these two laws revealed that the authority of the Senate was severely challenged. Also, Rome had set up a system that sought to prevent one man holding the power of command for a long period of time. For example, each consulship only lasted a year to limit the power of commanders. Yet, in the 1st century BCE, Pompeius was not only able to get a three year imperium but also got it extended through the support of his allies. This proves that the system of checks of balances was no longer effective in Rome, therefore violating Plato's definition of a republic and making Rome not a republic at this point.

In the last century of the traditionally considered Roman Republic, Pompeius and Caesar were both appointed the position of dictator. However, the nature of the Roman dictators had changed by this point. Comparing to consuls, dictators had higher authority over the state, which could be easily seen from their doubled number of servants. However, the duties of dictators were originally limited to commanding the Roman army, but not given any legal and other city management authorities. Also, dictators originally had a strict term of six months, and there were also checks on their powers. There were many instances throughout the Roman Republic in which tribunes vetoed dictators' policies. These checks and balances made sure that no man could hold absolute power in the state, qualifying as a functioning republic according to Plato's definition.

Initially, the Roman Republic established this temporary magistrate of dictator to deal with states of emergence under extreme circumstances. Its original intention was to concentrate all Roman resources to resolve the difficulties that the republic faced. However, by the second to the first century BCE, dictators gradually became the tools for powerful magistrates to gain full control over the state. The French philosopher and historian Montesquieu explained this trend in his book Considerations on the Causes of the Greatness of the Romans and their Decline, that "The most influential citizens asked people to entrust the special 
tasks and privileges to them in order to eliminate the powers of ordinary people and other magistrates, allowing one or several men to have absolute control over the state" [15].

In the late traditionally considered Roman Republic, the Roman society already displayed some aspects of an empire. One of the most influential historians who was also a Nobel Prize Laureate, Theodor Mommsen, wrote in his book A History of Rome that "after the death of Caesar, one man self-claimed to be the son of Marius in order to gain public support. This explained the reason that many Pompeius supports did not join Caesar's side after Pompeius' death. The reason being that Pompeius' two sons Gnaeus and Sextus were still alive and took over Pompeius' political inheritance" [16]. Sons inheriting their father's political influence was indeed factors of Empires. In the late Roman Republic, Marius' military reforms created professional armies which served generals' personal interests rather than the republic's. With private armies only being loyal to their commander instead of the republic, generals used the armies to impose pressure on the Senate and reduced its authority. Even though Rome did not have an emperor at this point, it had already become an empire.

\section{Findings and Analysis}

In this paper, the author discovers that both Plato and Cicero established the concepts of republics and empires as contradictions, for the limit of governmental powers does not exist in empires but does exist in republics. The author then analyzes the effects of the Gracchus Reform, which shaken the system of checks and balances within the Roman republic. Afterwards, the dictatorships of Caesar and Pompeius further reduced the function of checks of balances until Sulla's military reforms ultimately ended it.

\section{Conclusion}

In this paper, the author first defines the concept of a republic and an empire by analyzing the perspectives of two philosophers from different time periods, Plato and Cicero; then, he compares major events that occurred during the late Roman Republic, such as the Sulla Dictatorship, discovering that this so-called Roman republic has exhibited much of an empire's defining characteristics. First, the system of checks of balances, such as term limits, previously imposed on the consul by the Senate had collapsed. Second, the threat of using military might in defiance of the authority of the republican governing body became a new norm. In addition, the principle of popular sovereignty was replaced by the idea of concentrated authority under one man. Therefore, this paper concludes that Rome, once a republic, had transformed into an empire even before it had an emperor.

\section{Acknowledgements}

I wish to thank Prof. Richard Billows from Columbia University for research 
support. The author also wishes to thank Mrs. Christina Pitts-Kim from The King's Academy for helpful suggestions.

\section{Conflicts of Interest}

The author declares no conflicts of interest regarding the publication of this paper.

\section{References}

[1] Aristotle (2009) Politics. Oxford University Press, Oxford, 117.

[2] Brunt, P.A. (2013) "Amicitia” in the Late Roman Republic. The Cambridge Classical Journal, 11, 1-20.

[3] Plato (2004) Republic: A New Translation by Robin Waterfield. Oxford World Classics, Oxford, 261.

[4] Cicero (2002) Du re Publica. Wentworth Press, Sydney, 62.

[5] Pliny the Elder (1991) Naturalis Historia. Penguin Classics, London, 145.

[6] Karl Marx (2015) A Contribution to the Critique of Political Economy, Scholar's Choice.

[7] Billows, R.H. (2008) Julius Caesar: The Colossus of Rome. Routledge, London, 84. https://doi.org/10.4324/9780203412763

[8] Justinian (2014) Corpus Juris Civilis. Volume I, Chapter 2, CreateSpace Independent Publishing Platform, SScotts Valley, 238.

[9] Martino, F. (1974) Storia Della Costituzione Romana. Jovene, Milan, 179.

[10] Hoyos, D. (2015) Rome Victorious: The Irresistible Rise of the Roman Empire. 101.

[11] Montesquieu (2013) Considerations on the Causes of the Greatness of the Romans and their Decline. CreateSpace, Scotts Valley, 48.

[12] Mommsen, T. (2010) The History of Rome. Cambridge University Press, Cambridge, 73 .

[13] Durant, W. (1994) Caesar and Christ. Fine Communications, Ontario, 189

[14] Durant, W. (1994) Caesar and Christ. Fine Communications, Ontario, 190.

[15] Montesquieu (2013) Considerations on the Causes of the Greatness of the Romans and Their Decline. Createspace, Scotts Valley, 98.

[16] Mommsen, T. (2010) The History of Rome. Cambridge University Press, Cambridge, 417 . 